\title{
The Image of Woman in Ali Ahmad Bakathir's Literary World: A study of Selected Plays
}

\author{
Redhwan Qasem Ghaleb Rashed \\ Department of English -Faculty of Art-Hail University, Saudi Arabia \\ $\&$ \\ Department of English, Amran University, Yemen
}

\begin{abstract}
This research sheds light on an important area in Bakathir plays, woman's image, which has not been studied by any researcher to the best of my knowledge. An important objective of the study is to show how Bakathir portrays women in his selected plays and why his attitude towards women distinguishes his literary works among his contemporary writers. The significance of the study stems from the fact that such issues remain controversial and differs according to the writer ideology and background. Moreover, Bakathir, as well as his philosophy of woman is still unknown in the realm of world literature in general and contemporary Arabic literature in particular. The paper analyzes the image of women in Bakathir's plays: The Secret of Shahrazad (1951), Cats and Rats (1962) and The Tragedy of Zeinab(1966). However, the focus will be primary on The Secret of Shahrazad. It will display the way in which a woman is introduced and its relation to Bakathir's vision. It is clear that he presents an unprecedented splendid image for a woman in his plays. Not only does he highlight the woman in her bright images, yet he deliberately investigates the history and legends that encroach the holiness of the woman. He rectifies the history blunder and reinterprets the legends. The woman is portrayed in a positive and bright image, and the misconception that had been stickled to women for ages is tackled positively and logically. It is clear that Bakathir's portrayal of woman is colored by his own vision which is based on Islamic ideology.
\end{abstract}

Keywords: Ali Ahmad Bakathir, image, Shahrazad ,vision, woman, work

Cites as: Rashed, R. Q. G. (2019). The Image of Woman in Ali Ahmad Bakathir's Literary World: A study of Selected Plays. Arab World English Journal for Translation \& Literary Studies, 3 (1) 113-126. DOI: http://dx.doi.org/10.24093/awejtls/vol3no1.9 